\title{
Aikuisopintotukikokeilun tulokset myönteisiä
}

Opetusministeriön asettama Aikuisopintotukikokeilun seurantatyöryhmä luovutti laatimansa seurantatutkimuksen sekä ehdotuksensa aikuisopintotukikokeilun jatkotoimenpiteista opetusministeri Christoffer Taxellille toukokuun puolivälissä.

Työryhmä ehdotti aikuisopintotukikokeilua jatkettavaksi yhdellä vuodella 30.6 .1990 jälkeen, jolloin nykyinen kolmivuotinen kokeilukausi päättyy. Kokeilun jatkamisella on tarkoituksena saada lisäaikaa aikuisopintotuen rahoituspohjan laajentamista koskevaan selvitystyöhön.

Kokeilukauden jatkoajalla aikuisopintutuen määräytymisperusteet on tarkoitus pitää pääsääntöisesti ennallaan. Seurantatyöryhmä katsoo kuitenkin, että aikuisopintorahoihin osoitettu kiinteä määräraha tulisi muuttaa arviomäärärahaksi, jotta aikuisopiskelijoiden opiskelunaikaiset toimeentuloedellytykset voitaisiin taata.

Aikuisopintotukea myönnettiin vuonna 1988 noin 42 milj. markkaa. Vuodelle 1989 tarkoitukseen on varattu 65 milj. markan kiinteä määräraha. Lukuvuonna 1987-88 aikuistuen saajia oli 3600 henkilöä, joista 84 \% oli naisia. Lukuvuonna 1988-89 aikuistuen saajien määrän arvioidaan kaksinkertaistuvan.

Aikuisopintotuen saajista lukuvuonna 1987-88 oli 500 korkea-asteen opiskelijoita. Terveydenhuoltoalan koulutukseen aikuisopintukea sai 1700 opiskelijaa (49\%), kansanopisto-opintoihin 250, teknillisiin oppilaitoksiin 130, kauppa-oppilaitoksiin 170, ammattioppilaitoksiin 100 ja maa- ja metsätalousalan opintoihin 50 opiskelijaa. Muuhun ammatilliseen koulutukseen, mm. sosiaalialan, taidealan, kotitalous- ja kotiteollisuusalan opintoihin, aikuisopintotukea sai noin 600 opiskelijaa.

\section{Tuen riittävyys}

Tutkimus osoitti, että lähes puolelle aikuisopintotukea saaneista tuki riitti sellaisenaan kattamaan opiskelunaikaisen toimeentulon. Aikuisopintotuen suuruus oli opintovuonna 1987-88 oppilaitosryhmästä ja huollettavien lasten lukumäärästä riippuen keskimäärin 2900 - 3800 markkaa kuukaudessa. Aikuisopintorahan johdosta opiskelijan saama opintotuki oli kuukausitasolla noin 1030 markkaa suurempi kuin mitä opintotuki muuten olisi ollut. Aikuisopintorahan suuruus vaihtelee hakijan tulotasosta riippuen $700-2000$ markkaan kuukaudessa.

Puolet tuen saajista tarvitsi vielä lisärahoitusta opiskelun ajaksi. Lisärahoituksen tarve oli keskimäärin 500 markkaa kuukaudessa, mikä katettiin yleisimmin puolison tuloilla tai käyttämällä omia aikaisempia säästöjä taikka ottamalla pankkilainaa. Seurantatutkimus osoitti, että kokeiluvaiheen aikainen aikuisopintorahan vähimmäistaso samoin kuin aikuisopintorahan suhteellinen osuus tulotasosta saattaa olla määritelty liian alhaiseksi opiskelunaikaisen toimeentulon rahoitustarpeen kannalta. Kokeiluvaiheen aikaiset aikuisopintorahan vähimmäis- ja enimmäismäärät vahvistettiin vuoden 1986 tasolle eikä niitä ole sen jälkeen muutettu.

Aikuisopintotukea saaneen tuen tarpeeseen vaikuttaa olennaisesti heidän perheellisyytensä ja huoltovelvollisuutensa. Saajista neljä viidennestä oli perheellisiä ja keskimäärin he olivat kahden alaikäisen lapsen huoltajia. Myös asuntolainoista aiheutuvien taloudellisten sitoumusten hoitaminen opiskeluaikana aiheutti yleisesti rahoitustarvetta. 
Aikuisopintotuki suuntautuu keskeisesti henkilöille, joilta puuttui aikaisempi ammatillinen peruskoulutus ( $35 \%$ saajista) tai joiden aikaisempi koulutus oli vanhentunut tai vanhenemassa (56 \% saajista). Saajista oli nyt suorittamassa ammatillista tai korkea-asteentutkintoa 56 prosenttia ja jatko- tai täydennyskoulutuksessa 30 prosenttia. Näiden tekijöiden osalta aikuisopintotuki näyttäisi suuntautuvan odotetulla tavalla.

Ammatillisia ja korkea-asteen tutkintoja voidaan tällä hetkellä tukea silloin, kun niiden kesto on vähintään kahdeksan viikkoa. Korkeakouluissa suoritettavia arvosanaopintoja ei voida pääsääntöisesti tukea lainkaan. Vaikka pitkäkestoisen koulutuksen tukemista aikuisopintotuella pidettäisiinkin ensisijaisena, tulisi aikuistukijärjestelmää kehitettäessä tutkia myös mahdollisuudet suunnata taloudellista tukea myös ammatillisiin ja yleissivistäviin monimuoto-opintoihin.

Aikuisopintotuen laajentaminen koskemaan myös monimuoto-opintoja saattaisi edellyttää opintotuen rahoituksen uudelleen järjestelyä — ainakin määrärahan merkittävää lisäämistä - juuri rahoitustarpeen kasvun johdosta: monimuoto-opintoja harjoittavien määrä on suhteellisen suuri ja tämäntyyppisen koulutuksen järjestäminen aikuisväestölle on merkittävästi laajenemassa. Kokeiluvaiheen aikana ei näitä opintoja ole voitu ottaa tuen piiriin käytettävissä olevien varsin rajallisten määrärahojen johdosta.

\section{Työssäolovaatimus aiheutti hylkäämisiä}

Aikuisopintoraha hylättiin opintovuonna 1987-88 noin 1400 opiskelijalta. Keskeisiin hylkäämisen syy oli vaatimuksena olleen viiden vuoden työssäolon puuttuminen useimmiten niin, että lähimpään viisivuotiskauteen osui päätoimista opiskelua ( $22 \%$ hylätyistä). Myös ikäehdon - 30 vuotta - täyttymättä jääminen oli eräs yleisimpiä hylkäyssyitä (10 \%:lla hylätyistä).

Tutkimuksen tulokset osoittivat, että kokeilussa hyvin kaavamaisesti määritellyt ja joustamattomat työssäolo- ja ikäkriteerit eivät ota riittävästi huomioon välttämätöntä koulutustarvetta. Pitkäänkin ansiotyössä ollut on voinut saada hylkäävän päätöksen varsin lyhyen koulutusjakson tai työllisyyskoulutuksen osuessa lähimpään viisivuotiskauteen tai ikäehdon täyttyessä hieman lainsäädännön edellyttämän tutkinta-ajankohdan (1.7.) jälkeen.

Tuen myöntämiskriteereitä kehitettäessä tulisi saantiehtojen määrittelyä joustavoittaa siten, että yksilöllinen koulutustarve tulisi nykyistä keskeisemmin määrääväksi tekijäksi muiden ehtojen rinnalle, vaikka ne muuten olisivatkin kaavamaisia. Tämä aiheuttaisi luonnollisesti saajapiirin kasvamista ja siten määrärahatarpeen lisäystä, mutta oikaisisi kokeilun osoittaman olennaisen vääristymän myöntämisehdoissa.

Aikuisopintotuen saajat ovat useimmiten ansiotyöstä opintoihin siirtyneitä ( $82 \%$ ). Tuen saajista noin puolet oli saanut opintovapaata - neljännes oli ennen opintoihin siintymistä elämäntilanteessa, jossa opintovapaata ei tarvittu eikä siksi haettukaan. Saajista yhdeksän prosenttia ilmoitti saaneensa opintovapaa-anomukseensa kielteisen päätöksen.

\section{Aikuistuella merkittävä työllisyysvaikutus}

Kokeilukauden ensimmäinen opintovuosi on osoittanut aikuisopintotuella olevan myös merkittävän työllisyysvaikutuksen. Vaikutus on kahdensuuntainen: Yhtäältä se parantaa merkittävästi tuen saajan itsensä koulutuksellisia valmiuksia ja työllistymisedellytyksiä. Tuen saajista 93 prosenttia katsoi nykyisillä opinnoillaan olevan keskeinen merkitys työuralla ja ammatissaan etenemiseen.

Toisaalta opintoihin siirtyvän tilalle työpaikalle otetaan useimmiten sijainen. Tutkimustulosten perusteella voidaan arvioida, että opintovuonna 1987-88 noin 2700 aikuisopintotuen saajan tilalle on otettu sijainen. Koulutuspituuksien perusteella voidaan laskea, että sijaisuudet ovat kestäneet 4-9 kuukautta lukuvuoden aikana.

Vaikka seurantatutkimus rajoittuukin opintovuoteen 1987-88, voitaneen tulosta soveltaa myös opintovuoteen 1988-89; Kun tuen saajia on tällä hetkellä noin 7000 , on noin 5200 opiskelijan tilalle otettu sijainen työpaikalle. Seurantatutkimuksen tuloksella on olennaista merkitystä laskettaessa aikuisopintotuen yhteiskunnallisia kustannuksia.

Varovaisestikin arvioiden aikuisopintorahaan suunnatut määrärahat säästyvät toisaalla - erityisesti työttömyysturvamenoissa. Aikuisopintorahoihin käytettiin opintovuonna 198788 noin 28 milj. markkaa. Olettaen, että opiskelemaan siirtyneen työpaikalle otettu sijainen oli työtön, jonka työttömyyspäivärahan suuruus oli 85 markkaa ja sijaisuuden kesto seitsemän kuukautta, syntyi työttömyyspäivära- 
hoissa säästöä vastaavana aikana noin 35 milj. markkaa. Kun keskimääräinen työttömyysturvan päiväraha on todennäköisesti mainittua suurempi, on aikuisopintorahamenojen ja muualla tapahtuvien säästöjen erotus mainittua suurempi.

Aikuisopintotukikokeilun ehkä merkittävin heikkous itse kokeilun onnistumisen kannalta on ollut määrärahan luonne: aikuisopintoraha on ollut valtion tulo- ja menoarviossa kiinteä. Määrärahan luonteen johdosta tuen hakijat eivät ole voineet etukäteen varmistua tuen saannista. Kuitenkin opiskelupaikan saatuaan opiskelijan on haettava opintovapaata jo hyvissä ajoin ennen opintojen alkua tietämättä varmuudella sitä, saako hän ansiotulojensa sijalle mahdollisesti aikuisopintotukea vai ei.

Aikuisopiskelijan rahoitustarpeet edellyttäisivät varsin luonnollisesti selkeyttä taloudellisesti turvatusta opiskelusta. Aikuisopintotukijärjestelmää kehitettäessä tulee taloudellisen turvan varmuuteen määrärahan luonteen puolesta kiinnittää erityistä huomiota. Valtioneuvoston periaatepäätös ammatillisen aikuiskoulutuksen kehittämisestä edellyttäisi omaehtoisen opiskelun tuen järjestämistä arviomäärärahaperusteisesti, jotta toimeentulo opiskeluaikana voitaisiin taata - etukäteen ja varmuudella. 